\title{
DEGRADASI HUTAN BAKAU AKIBAT PENGAMBILAN KAYU BAKAR OLEH INDUTRI KECIL GULA KELAPA DI CILACAP
}

\author{
Tumisem, Suwarno \\ Fakultas Keguruan dan Ilmu Pendidikan \\ Universitas Muhammadiyah Purwokerto \\ Jl. Raya Dukuhwaluh PO. BOX 202 Kembaran Purwokerto \\ Telp. 081328707320; \\ E-mail: umiump@yahoo.com
}

\begin{abstract}
A Study on degradations mangrove forest due to firewood exploitation by coconut palm sugar home industry in Cilacap. Information on social economic aspect and respons of coconut palm sugar home industry to using fuel substitutions were collected by using a questioner. The potential of mangrove as a firewood source was estimated by quadrat method. The study bas been carried out on dry and rainy season. The wood production of available 8000 ba of mangrove from Cilacap primarily Rhizophora apiculata Linn and Rhizophora mucronata Lamk were 3.249.920 $\mathrm{m}^{3}$. The results showed that the declining of mangrove was about 19,250 $\mathrm{m}^{2}$ in dry season and 26,551 $\mathrm{m}^{2}$ in rainy season, this was correlated with the amount of nira to be processed that was $0,782 \mathrm{~m}^{3}$ in dry season and 1,079 $\mathrm{m}^{3}$ in rainy season. Deforestation of mangrove forest due to change of mangrove zonation. Rhizophora apiculata Linn and Rhizophora mucronata Lamk will be domination Nypa fruticans, that is shown superficiality to continent form.
\end{abstract}

Keywords: degradations, mangrove, firewood exploitation, coconut palm sugar home industry.

\section{PENDAHULUAN}

Hutan mangrove mempunyai fungsi ganda, yaitu dari segi ekologis dan sosial ekonomi. Dari segi ekologis misalnya sebagai tempat berpijah atau berkembangbiak berbagai jenis biota air termasuk ikan dan udang, dan sosial ekonomi misalnya sebagai tempat mencari ikan, udang, dan kepiting, dan sumber kayu bakar. Kawasan mangrove di Cilacap berbatasan dengan Segara Anakan. Di dalam kawasan mangrove Cilacap terdapat beberapa daerah pemukiman antara lain: desa Ujung Alang, Ujung Gagak, Pamotan dan Jojok Kutawaru. Matapencaharian penduduk yang tinggal di kawasan mangrove sebagian besar sebagai nelayan tradisional yang menangkap ikan di sekitar Segara Anakan. Di Segara Anakan terdapat muara beberapa sungai besar seperti Sungai Citanduy, Sungai Donan, Sungai Cibeureum, Sungai Cikonde dan sungai-sungai kecil lainya. Sungai-sungai yang bermuara di Segara Anakan banyak membawa partikel-partikel tanah, menyebabkan tingkat sedimentasi di Segara Anakan cukup tinggi. Sedimentasi merupakan salah satu sistem terjadinya penurunan produksi perikanan tangkap nelayan tradisional di sekitar Segara Anakan (Roesmidi 1998). Menurut Kepala Desa Jojok Kutawaru (komunikasi personal), penurunan hasil perikanan tangkap, menyebabkan sebagian besar nelayan terutama desa Cimeong dan Cigintung beralih menjadi pengusaha atau pekerja industri kecil kelapa tradisional (home industry) dan petani pasang surut. Perkembangan industri kecil 
gula kelapa dimulai sekitar tahun 1993 sampai saat ini. Industri kecil gula kelapa tersebut memasak nira menggunakan kayu bakar mangrove. Untuk memproduksi gula kelapa yang baik, dibutuhkan bahan yste berkualitas baik. Kayu mangrove sebagai bahan bakar untuk memproduksi gula kelapa terutama Rhizophora sp memiliki kualitas yang baik, karena memiliki nilai kalor yang cukup tinggi yaitu 4.000-4.300 Kkal/kg (Hilal dan Syaffriadi 1997). Umumnya tingkat konsumsi kayu bakar industri kecil gula kelapa pada musim penghujan 2 kali tingkat konsumsi kayu bakar pada musim kemarau, karena jumlah nira yang diperoleh pada musim penghujan lebih banyak.

Luas hutan mangrove di Cilacap terus mengalami penyusutan, yang semula sekitar 15.551 ha pada tahun 1974 saat ini menjadi sekitar 8.000 ha. Penyusutan luas hutan mangrove antara lain bersumber dari kegiatan manusia yang mengkonversi areal mangrove menjadi pemukiman, kegiatan komersial/industri, pertanian dan eksploitasi yang berlebihan terhadap vegetasi mangrove menjadi kayu bakar (Haeruman1987; Rahayu 1994). Berkembangnya industri kecil gula kelapa di sekitar kawasan mangrove yang mengambil kayu bakar mangrove merupakan salah satu sistem yang ikut mempercepat penyusutan hutan mangrove di Cilacap. Penyusutan ini terlihat jelas pada hutan mangrove yang terletak di sebelah Barat desa Cimeong dengan luas sekitar 112 ha telah berubah menjadi lahan kosong dan sekitar 38 ha lainnya hanya terdiri dari jenis Nypa fruticans dan semak (Perhutani, 1998). Sampai saat ini, belum ada bahan bakar pengganti kayu mangrove yang tepat dengan harga yang terjangkau oleh industri kecil gula kelapa di Kelurahan Jojok Kutawaru.
Berdasarkan latar belakang permasalahan di atas dapat dikemukakan bahwa penyusutan hutan mangrove banyak bersumber dari kegiatan manusia yang mengkonversi areal mangrove menjadi pemukiman, kegiatan komersial/industri, pertanian dan eksploitasi yang berlebihan terhadap vegetasi mangrove menjadi kayu bakar. Sampai saat ini pendataan penyusutan hutan mangrove yang dilakukan oleh pihak Perhutani Cilacap dianalisis secara umum dan menyeluruh, sehingga masingmasing kegiatan manusia terkait dengan penyusutan hutan mangrove tersebut di atas belum ada menunjukkan angka nyata (Perhutani, 1998). Hal ini mengakibatkan sistem utama penyusutan hutan mangrove belum terdeteksi secara pasti. Untuk melengkapi salah satu data penyusutan hutan mangrove akibat pengambilan kayu bakar oleh home industry gula kelapa dilakukan pendataan jumlah pengrajin yang ada di sekitar kawasan mangrove dan analisis konsumsi kayu bakar mangrove pada musim penghujan dan kemarau.

\section{METODE}

Penelitian ini dilakukan di empat desa sekitar kawasan mangrove Cilacap. Lokasi ini ditentukan berdasarkan data statistik penduduk yang menyebutkan bahwa industri kecil gula kelapa sekitar kawasan mangrove Segara Anakan terdapat di desa Jojok-Kutawaru, Cimeong dan Cigintung.

Analisis jumlah industri kecil gula kelapa sekitar kawasan mangrove dilakukan melalui pendataan langsung bekerjasama dengan masing-masing kepala lingkungan. Kepala lingkungan merupakan petugas yang dipilih masyarakat untuk membawahi suatu wilayah tertentu di seki- 
tar kawasan mangrove sebagai pengganti kepala dusun. Tugas-tugas kepala lingkungan sama dengan tugas kepala dusun. Perlu diketahui bahwa di kawasan mangrove terdapat empat kepala lingkungan artinya di kawasan mangrove sekitar segara anakan memiliki empat desa yang di kepalai oleh Kepala Lingkungan.

Jumlah kayu bakar yang digunakan oleh industri kecil gula kelapa diketahu melalui:

\section{Pemilihan industri kecil kelapa sebagai responden}

Jumlah industri kecil kelapa yang digunakan untuk memperoleh informasi mengenai pemakaian kayu bakar dipilih secara acak sebanyak 10\% dari jumlah seluruh industri kecil (Sutrisno Hadi 1983). Jumlah $10 \%$ dari seluruh pengrajin selanjutnya dalam penelitian disebut sebagai responden.

\section{Jenis dan jumlah kayu bakar}

Untuk mendapatkan informasi mengenai jenis kayu bakar yang digunakan masing-masing responden dilakukan pengamatan langsung di lapangan terhadap karakteristik tumbuhan. Pengamatan langsung dilakukan bersama dengan Staf Perhutani dan pencari kayu yste, sedangkan wawancara dilakukan terhadap seluruh industri kecil kelapa di desa Cimeong dan Cigintung.

Untuk mengetahui informasi mengenai jumlah kayu bakar yang digunakan oleh masing-masing responden digunakan penghitungan langsung jumlah kayu bakar di lapangan. Untuk mengetahui ketelitian data volume yang dipergunakan masing-masing responden, maka dilakukan penghitungan langsung di lapangan pada masing-masing responden. Penghitungan langsung volume masing-masing responden dilakukan 3 hari seminggu selama 4 minggu.

\section{Penyusutan Mangrove dan dampaknya}

Untuk mengetahui penyusutan hutan mangrove dilakukan dengan cara menghitung volume produksi kayu mangrove yang tersedia pada area tertentu dikurangi dengan volume kayu bakar yang digunakan oleh industri kecil gula kelapa. Volume produksi kayu mangrove yang tersedia dilakukan melalui ploting (Gambar 1.1), pengukuran karakter tegakan, penghitungan luas basal area tegakan, kemudian dilanjutkan dengan menghitung volume produksi kayu mangrove yang tersedia. Jumlah plot yang dibuat sebanyak 5 plot dengan ukuran masing-masing plot $=5 \mathrm{mX} 5 \mathrm{~m}$. Volume produksi kayu mangrove yang tersedia menurut (Bonham 1989) digunakan rumus sebagai berikut:

Lba total tegakan A X rata-rata Tt A X 0,7 (dimana 0,7 adalah faktor koreksi)

Lba total tegakan $\mathrm{A}=$ Lba rata-rata tegakan A X Kerapatan A

\section{HASIL DAN PEMBAHASAN}

\section{Jumlah Industri kecil dan Penggunaan Kayu Bakar Mangrove}

Hasil penelitian menunjukkan jumlah seluruh industri kecil gula kelapa yang berada di kawasan lingkungan sekitar mangrove 400 buah terdiri atas: Kelurahan Jojok-Kutawaru, Cimeong, Cigintung. Umumnya industri kecil kelapa di desa Cimeong dan Cigintung saat memasak nira menggunakan Rhizophora apiculata Linn dan Rhizophora mucronata Lamk sebagai bahan bakar memasak nira. Kayu bakar yang 


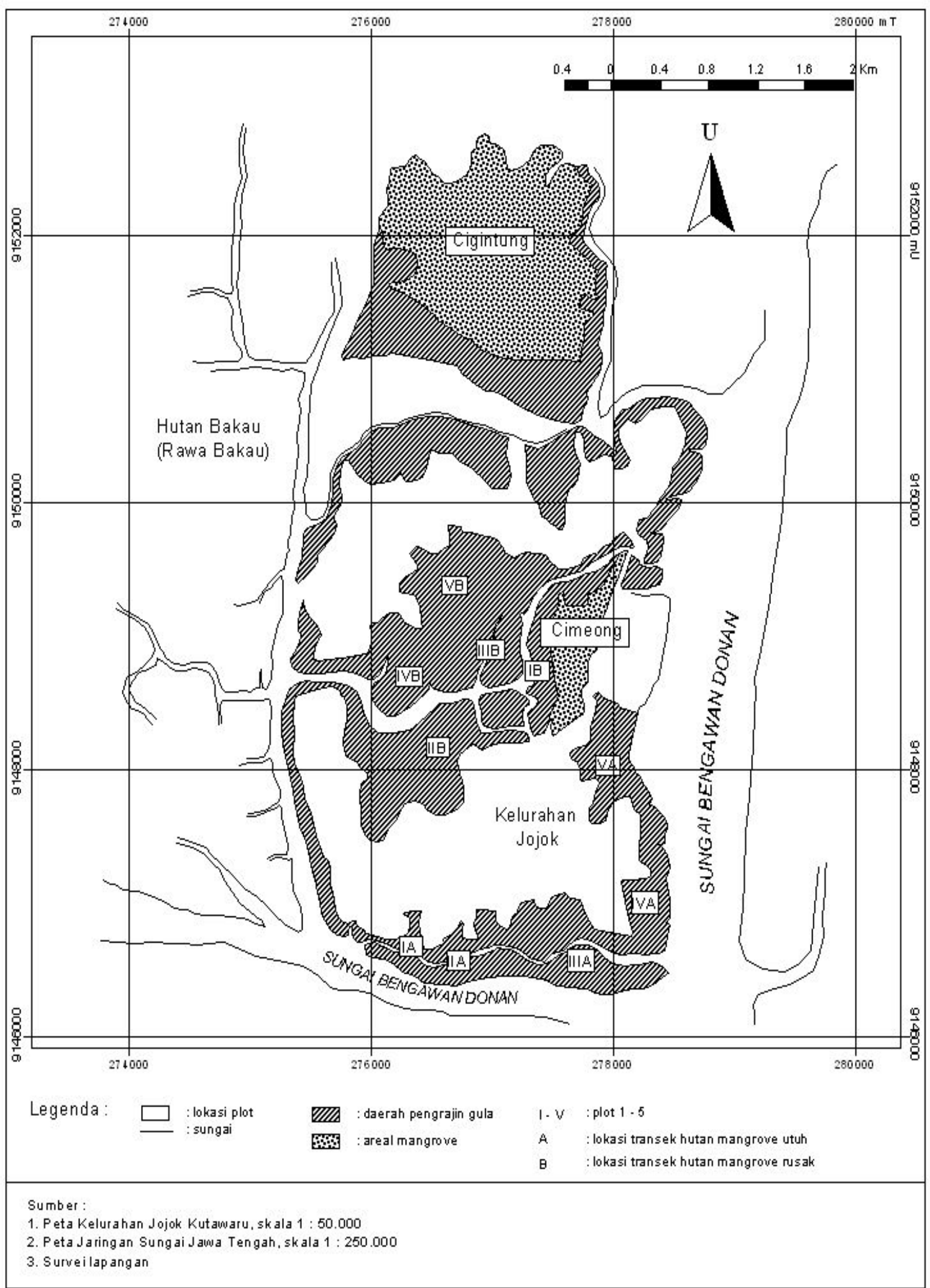

Gambar 1. Lokasi Penelitian dan Ploting Di kawasan Mangrove Sekitar Segara Anakan Cilacap. (Peta Monografi Desa, 2007). 
Tabel 1. Jumlah Industri Kecil, Perolehan Kayu Bakar, dan Jenis Kayu yang Digunakan

\begin{tabular}{|c|c|c|c|c|c|}
\hline \multirow{2}{*}{ No. } & \multirow{2}{*}{ Desa } & \multirow{2}{*}{$\begin{array}{c}\text { Jumlah Industri } \\
\text { Kecil }\end{array}$} & \multicolumn{2}{|c|}{ Perolehan Kayu Bakar } & \multirow{2}{*}{$\begin{array}{c}\text { Jenis Kayu Mangrove } \\
\text { yang Digunakan }\end{array}$} \\
\hline & & & Dari hutan & Beli dari pengepul & \\
\hline 1. & Cimeong & 80 & 5 & 75 & \multirow{3}{*}{$\begin{array}{l}\text { Rhizophora apiculata } \\
\text { Rhirophora mucronata }\end{array}$} \\
\hline 2. & Cigintung & 120 & 6 & 114 & \\
\hline 3. & Jojok & 200 & 200 & - & \\
\hline & Jumlah & 400 & 211 & 189 & \\
\hline
\end{tabular}

digunakan diperoleh melalui dua cara yaitu membeli kayu bakar ke pengepul dan mengambil langsung dari huta mangrove di sekitarnya (Tabel 1.).

Hasil penelitian menunjukkan bagi industri kecil yang menyadap pohon kelapa antara 10 - 19 pohon, umumnya membeli kayu bakar dalam bentuk ikatan. Bila jumlah pohon yang disadap lebih dari 20, akan membeli kayu bakar dalam bentuk kubikan. Satu ikat kayu bakar yang digunakan sama dengan $1 / 7 \mathrm{~m}^{3}$. Jumlah kayu bakar yang digunakan oleh masingmasing industri kecil antara musim penghujan dan kemarau berbeda. Hal ini disebabkan jumlah nira antara musim kemarau dengan penghujan juga berbeda.

Hasil analisis menunjukkan jumlah rata-rata kayu bakar yang dipakai oleh industri kecil pada musim kemarau yaitu $0,782 \mathrm{~m}^{3}$ dengan jumlah nira rata-rata yang diperoleh sebanyak 66,99 liter. Pada musim penghujan jumlah rata-rata kayu bakar yang dipakai $1,079 \mathrm{~m}^{3 .}$ dengan jumlah nira ratarata yang diperoleh sebanyak 84,711 liter.

\section{Penyusutan Luas Hutan Mangrove Akibat Pengambilan Kayu Bakar}

Rata-rata kepadatan Rhizophora apiculata di lokasi yang masih alami (utuh)
$5 / 25 \mathrm{~m}^{2}$ dan Rhizophora mucronata $3 / 25 \mathrm{~m}^{2}$. Rata-rata diameter batang Rhizophora apiculata y 4,99 cm dan Rhirophora mucronata $4,92 \mathrm{~cm}$ dengan rata-rata tinggi tegakan Rhizophora apiculata 6,54 $\mathrm{m}$ dan Rhizophora mucronata 5,60 m. Rata-rata luas basal area Rhizophora apiculata $19,63 \mathrm{~cm}^{2}$ dan Rhizophora mucronata 19,08 $\mathrm{cm}^{2}$ (Tabel 2 dan Tabel 3).

Hasil analisis terhadap produksi kayu dari Rbizophora apiculata yang tersedia saat ini dengan luas hutan mangrove sekitar 8.000 ha adalah $3.121 .920 \mathrm{~m}^{3}$ dan untuk Rhirophora mucronata adalah $128.000 \mathrm{~m}^{3}$, sehingga produksi total kayu mangrove sebagai bahan bakar memasak nira yang tersedia adalah $3.249 .920 \mathrm{~m}^{3}$. Rata-rata luas hutan mangrove yang dibutuhkan untuk memenuhi kebutuhan kayu bakar pada musim kemarau adalah 19,250 $\mathrm{m}^{2}$ dan musim penghujan adalah $26,551 \mathrm{~m}^{2}$.

\section{Dampak Pengambilan Kayu Man- grove terhadap Perubahan Zonasi Mangrove}

Hasil analisis data yang diperoleh dari lapangan menunjukkan bahwa di lokasi yang masih utuh nilai penting tertinggi terdapat pada Rhizophora apiculata sebesar 68,64\%, diikuti oleh Bruguiera gymnorrbiza $(65,22 \%)$, Avicenia alba (43,48\%), 
Tabel 2. Jumlah, diameter batang (Db), tinggi tegakan (Tt) dan luas basal area (Lba) dari Rhizophora apiculata ( $\mathrm{Ra}$ ) di lokasi yang masih utuh

\begin{tabular}{|c|c|c|r|r|r|}
\hline No. & Stasiun & $\Sigma \mathrm{R} a$ & $\mathrm{Db}(\mathrm{cm})$ & \multicolumn{1}{c|}{$\mathrm{Lba}\left(\mathrm{cm}^{2}\right)$} & \multicolumn{1}{|c|}{$\mathrm{Tt}(\mathrm{m})$} \\
\hline 1 & I & 4 & 4,78 & 17,94 & 10,23 \\
\hline 2 & II & 5 & 5,01 & 19,70 & 9,55 \\
\hline 3 & III & 6 & 4,91 & 18,92 & 9,50 \\
\hline 4 & IV & 4 & 5,22 & 21,39 & 10,10 \\
\hline 5 & V & 4 & 5,07 & 20,18 & 10,34 \\
\hline Rataan & & 5 & 4,99 & 19,63 & 9,94 \\
\hline
\end{tabular}

Tabel 3. Jumlah, diameter batang (Db), tinggi tegakan (Tt), dan luas basal area (Lba) dari Rhirophora mucronata $(\mathrm{Rm})$ di lokasi masih utuh

\begin{tabular}{|c|c|c|r|r|r|}
\hline No. & Stasiun & $\Sigma R m$ & \multicolumn{1}{|c|}{$\mathrm{Db}(\mathrm{cm})$} & \multicolumn{1}{c|}{ Lba $\left(\mathrm{cm}^{2}\right)$} & \multicolumn{1}{c|}{$\mathrm{Tt}(\mathrm{m})$} \\
\hline 1 & I & 4 & 4,22 & 13,98 & 7,24 \\
\hline 2 & II & 2 & 5,01 & 19,70 & 6,56 \\
\hline 3 & III & 3 & 5,32 & 22,22 & 7,34 \\
\hline 4 & IV & 2 & 5,12 & 20,58 & 6,52 \\
\hline 5 & V & 2 & 4,92 & 19,00 & 7,32 \\
\hline Rataan & & 3 & 4,92 & 19,08 & 6,99 \\
\hline
\end{tabular}

Rhizophora mucronata (34,09\%), Sonneratia alba $(27,92 \%)$, Ceriops tagal (24,65\%), Xylocarpus mollucensis $(20,92 \%)$ dan Nypa fruticans $(15,08 \%)$ (Tabel 4). Di lokasi penebangan nilai penting tertinggi terdapat pada Nypa fruticans yaitu $122,29 \%$, diikuti oleh Bruguiera gymnorrbiza (64,09\%), Rhizophora apiculata (30,49\%), Xylocarpus mollucensis $(28,92 \%)$, Rhizophora mucronata (27,55\%) dan Ceriops tagal (26,68\%) ( Tabel $5)$.

Menurut pengakuan industri kecil (komunikasi personal), kayu Rhizophora apiculata dan Rhizophora mucronata mem- punyai nyala api yang baik, awet dan mudah dinyalakan. Nyala api yang baik dari Rhizophora apiculata dan Rhizophora mucronata disebabkan karena kayu Rhizophora apiculata dan Rhizophora mucronata mempunyai kepadatan yang cukup tinggi. Kayu dengan kepadatan yang tinggi akan menjadi lebih berat (rata-rata $0,9 \mathrm{~m} / \mathrm{s}^{2}$ ), keras, mempunyai daya keawetan yang lama dan merupakan bahan bakar yang baik dengan panas yang ditimbulkan cukup tinggi serta nyala apinya cukup lama. Namun demikian gas-gas pembakaran dari kayu tersebut dapat menimbulkan karat pada logam (Anonim 1998; Duke, \& Bunt 
Tabel 4. Analisis vegetasi di lokasi yang tidak terganggu, meliputi frekuensi Kayu bakar (Fr), kepadatan kayu bakar (Kpr), kerimbunan kayu bakar (Kbr), dan nilai penting (NP).

Tabel 5. Analisis vegetasi di lokasi terganggu, meliputi frekuensi kayu bakar (Fr), kepadatan kayu bakar (Kpr), kerimbunan kayu bakar (Kbr), dan nilai penting (NP).

\begin{tabular}{|c|c|c|c|c|c|c|}
\hline No. & Jenis & Fr $\mathrm{Fr}$ & KprKpr & KbłKbr & NPNP & \\
\hline 1. & Rhirophora apicullatta & 163,68 & 22,454 & 32.088 & 680,64 & \\
\hline 2. & Rhirophora mucronata & 13,116 & 12,754 & 8,.BB) & $34,(555$ & \\
\hline 3. & Avicenia alba & $-13,16$ & $-14,71$ & $1-5,61$ & 43,48 & \\
\hline 4. & Bruguiera gymmorrbiza & 116,68 & $20,2.3$ & 35,52 & 655420 & \\
\hline 5. & Xylocarpus mollucensis & 16,60 & 5,88 & 13,88 & 283,922 & \\
\hline 6. & Ceriops tagal & $16,6,68$ & 8,82 & $2, .85$ & 24,658 & \\
\hline 7. & Sonneratidotbon). Hal ini sesuai & dengatiplen & lapat - 4,98i & at-sif2, $86 a$ & na dern.gan & nayu Rhirophora \\
\hline 8. & Nypa frutidalaku industri kecil (ko & nunikagizers & pnal), GB,,T24 & iculato39,358 & Rhirq & prucronata. \\
\hline
\end{tabular}
lebih tebal dan cepat keropos. Keadaan wajan yang bertambah tebal membuat proses pembuatan gula menjadi lebih lama dan pemakaian kayu bakar meningkat. Pemakaian kayu bakar mangrove menurut pengakuan pengrajin juga disebabkan karena kayu bakar yang berasal dari pekarangan sendiri tidak mencukupi dan tidak ada kayu bakar pengganti yang memiliki

Umumnya pembelian kayu bakar sebanyak $1 \mathrm{~m}^{3}$ akan diantar ke alamat pembeli menggunakan gerobak, sedangkan dalam bentuk ikatan si pembeli mengambil sendiri. Jumlah kayu bakar yang dipakai industri kecil gula kelapa tergantung pada jumlah nira yang diperoleh. Jumlah nira yang diperoleh industri kecil gula kelapa dipengaruhi oleh jumlah pohon yang disa- 
dap dan musim. Umumnya mayang kelapa yang disadap dalam satu pohon berkisar antara $2-3$ mayang. Pada musim penghujan, menurut industri kecil kelapa (komunikasi personal), dua mayang kelapa yang disadap menghasilkan nira sama dengan tiga mayang pada musim kemarau, sehingga jumlah nira yang diperoleh pada musim tersebut akan lebih banyak. Jumlah nira kelapa pada musim penghujan yang lebih banyak disebabkan karena ikut masuknya air hujan ke dalam penampung nira (pongkor). Jumlah nira yang banyak pada musim penghujan juga disebabkan karena kadar air dalam tubuh tanaman cukup tinggi. Sebagai upaya untuk memelihara keseimbangan kadar air dalam tubuh tanaman dengan kondisi lingkungannya, maka tanaman mengeluarkan air dari dalam tubuhnya melalui organ ekskresi. Dalam hal ini karena adanya luka pada mayang kelapa, maka kadar air dalam tubuh tanaman juga akan dikeluarkan melalui luka tersebut disamping senyawa-senyawa lainnya yaitu sukrosa (Hilal dan Syaffriadi 1997; Karimuddin 1995).

Kegiatan pengambilan kayu mangrove dilakukan dengan cara mencuri (di desa Cigintung terdapat 6 orang sebagai pengambil kayu bakar dan juga sebagai pelaku industri, dan di desa Cimeong terdapat 5 orang). Pencurian kayu dilakukan dengan alasan untuk menambah penghasilan karena pohon yang disadap sedikit (10-12 pohon), sehingga hasil gula yang diperoleh sedikit dan pendapatan yang diperoleh juga sedikit. Pengambilan kayu selain untuk digunakan sendiri dalam memasak nira juga dijual ke industri kecil lainnya yang membutuhkan kayu bakar. Penjualan kayu bakar mangrove hanya berkisar di sekitar desa Cimeong dan Cigintung. Pengambilan kayu bakar mangrove oleh industri kecil gula kelapa memberatkan tekanan pada daerah-daerah konservasi mangrove, terutama pada kawasan yang letaknya berdekatan dengan pemukiman penduduk.

Dalam upaya membantu mencukupi kebutuhan kayu bakar, Perhutani telah mengijinkan industri kecil gula kelapa maupun masyarakat sekitar kawasan mangrove mengambil kayu mangrove dengan ketentuan bahwa pengambilan kayu mangrove hanya dilakukan terhadap tanaman selain tanaman pokok yaitu Rhizophora apiculata, Rhizophora muconata, dan Bruguiera gymnorrbiza, tetapi industri kecil gula kelapa ternyata masih tetap mengambil tanaman pokok mangrove sebagai bahan bakar memasak nira kelapa terutama Rbizophora apiculata dan Rhizophora mucronata. Pengambilan kayu mangrove yang dilakukan tiap hari oleh industri kecil gula kelapa tanpa adanya pengawasan yang ketat oleh Perhutani mengakibatkan penyusutan hutan mangrove di Cilacap semakin cepat. Penyusutan hutan mangrove yang cepat akibat pengambilan kayu bakar oleh industri kecil gula kelapa terjadi pada musim penghujan, yang masih memungkinkan industri kecil gula kelapa melakukan penyadapan mayang kelapa.

Di lokasi mangrove yang tidak terganggu, zona depan didominasi oleh Rhizophora apiculata, Avicenia alba, Bruguiera gymnorrbiza dan Rhizophora mucronata. Penyusutan mangrove akibat pengambilan kayu bakar oleh industri kecil gula kelapa di zona depan (zona Rhizophora apiculata dan Rhizophora mucronata), menyebabkan terjadinya perubahan zonasi vegetasi mangrove. Perubahan yang terjadi yaitu bahwa pada lokasi tidak terganggu zona terdepan didominasi oleh Rhirophora apiculata, sedang 
pada lokasi terganggu zona terdepan berubah menjadi didominasi oleh $N y p a$ fruticans yang berasosiasi dengan Bruguiera gymnorrbiza. Pada lokasi mangrove yang mengalami kerusakan paling berat akibat pengambilan kayu bakar mangrove sebagai bahan bakar oleh industri kecil gula kelapa mengakibatkan sebagaian besar area mangrove menjadi lahan kosong/daratan.

\section{KESIMPULAN}

Dari penelitian di atas dapat disimpulkan bahwa:

1. Jumlah kayu bakar yang digunakan industri kecil pada musim penghujan rata-rata $1,079 \mathrm{~m}^{3}$ dengan jumlah nira sebanyak 84,711 liter. Pada musim kemarau rata-rata $0,782 \mathrm{~m}^{3}$ dengan jumlah nira sebanyak 66,99 liter.

2. Pengambilan kayu bakar sebanyak $1,079 \mathrm{~m}^{3}$ menyebabkan penyusutan luas hutan mangrove sekitar 26,551 $\mathrm{m}^{2}$ dan pengambilan kayu bakar sebanyak $0,782 \mathrm{~m}^{3}$ menyebabkan penyusutan luas mangrove sekitar 19,250 $\mathrm{m}^{2}$.

3. Penyusutan luas mangrove terjadi terutama pada zona Rhizophora apiculata dan Rhizophora mucronata menyebabkan terjadinya perubahan zonasi mangrove yaitu zona terdepan yang terdiri atas Rhizophora apiculata dan Rhizophora mucronata di lokasi utuh digantikan oleh Nypa fructicans yang berasosiasi dengan Bruguiera gymnorrbiza.

\section{SARAN}

Sebagai upaya untuk melestarikan mangrove, menyediakan kayu bakar, meningkatkan ekonomi masyarakat sekitar dan menjaga siste penyangga kehidupan di sekitarnya perlu dilaksanakan:

a. Hutan kemasyarakatan melalui KTHM (Kelompok Tani Hutan Mangrove)

b. Pengembangan pemanfaatan ganda mangrove

c. Peraturan Perundang-undangan secara tegas

d. Pengembangan sumberdaya manusia khususnya di sekitar mangrove

e. Pembentukan KUB (Kelompok Usaha Bersama)

f. Menjalin kerjasama antar instansi terkait untuk keberhasilan pengelolaan mangrove dan pengembangan industri kecil gula kelapa

\section{DAFTAR PUSTAKA}

Anonim. 1998. Kondisi Cuaca di Cilacap. Badan Meterologi Kabupaten Cilacap. 1998. Daftar Monografi Desa. Cilacap Tengah. Kabupaten Cilacap.

Agus Anggoro Sigit dan Suharjo. 2007. "Analisis Proses Degradasi Lahan dan Dampaknya terhadap Produktivitas Lahan Pertanian di Kabupaten Klaten”. Forum Geografi, Vol. 21, No. 2, Desember 2007. Hlm 155-173.

Bonham, Charles D. 1989. Measurements for Terrestrial Vegetation. Colorado State university Fort Collins. Colorado. P 19-66

Duke, N.C. \& Bunt, J.S. 1979. The Genus Rhizophora (Rhizoporaceae) in North Eastern Autralia. Aus J Bot 27. p. 657-678 
Haeruman, H.1987. Membina Peranan Kayu Rakyat di Jawa. Diskusi pembinaan dan pengembangan kayu rakyat, 9 - 10 Juli 1987. Bandung. Hal. 11-16

Hilal, H dan Syaffriadi. 1997. Pemanfaatan Sumber Energi untuk Mendukung Pembangunan berkelanjutan. Jurnal Studi Pembangunan Institut Teknologi Bandung Vol. 1 No. 2. Bandung. Hal 1-2.

Karimuddin, Y. 1995. Fungsi Ekologi, Tekanan Penduduk dan Sistem Pengelolaan Lahan Bakau di Kawasan Pantai Sumatera Selatan. PPLH UNSRI. Hal 6-11

Perhutani. 1998. Perkembangan Mangrove dan Struktur Vegetasi Mangrove di Cilacap. Perhutani Kabupaten Dati IICilacap.

Rahayu, S. 1994. Mengikutsertakan Masyarakat Pedesaan dalam Proyek Pembangunan Hutan Berskala Kecil. Journal of forestry research and development Vol. IX. No. 2. hal $73-79$.

Roesmidi. 1998. Proyek Konservasi dan Pembangunan Segara Anakan: Status dan Permasalahannya. BAPPEDA Tingkat II Cilacap. Hal 1-11

Sajogyo. 1987. Ekologi Pedesaan. Penerbit: Yayasan Obor. Jakarta. Hal 223-253

Sutrisno Hadi. 1983. Metodologi Research (Jilid III). Andi Offset. Yogyakarta. Hal 221 